\title{
Metallurgical Characterization of API X65 Steel Joint Welded by MIG Welding Process with Axial Magnetic Field ${ }^{1}$
}

\author{
Constantino Natividad ${ }^{\star} *$, Rafael García ${ }^{a}$, Victor H. López ${ }^{a}$, Antonio Contreras ${ }^{b}$, Melchor Salazar $^{b}$ \\ ${ }^{a}$ Instituto de Investigación en Metalurgia y Materiales, Universidad Michoacana de San Nicolás de \\ Hidalgo, Edificio "U”, Ciudad Universitaria, C.P. 58030, Morelia, Michoacán, México \\ ${ }^{b}$ Instituto Mexicano del Petróleo, Eje Central Lázaro Cárdenas Norte, 152, Col. San Bartolo \\ Atepehuacán, C.P. 07730, México
}

Received: March 1, 2016; Revised: August 4, 2016; Accepted: September 18, 2016

\begin{abstract}
In this work, API X-65 pipeline steel non-conventionally heat treated, to enhance its mechanical resistance, was welded using the Metal Inert Gas (MIG) process with and without the application of low intensity axial magnetic fields $(6 \mathrm{mT})$. Microstructural and mechanical characterization of the welds revealed that the use of the magnetic field during welding improved the toughness of the welds and therefore increased their mechanical strength. Failure of the welds occurred far from the weld beads. The electromagnetic stirring of the weld pool significantly reduced the levels of porosity in the weld beads and favored columnar grain growth due to the ferromagnetic nature of the base metal and filler wire. Impact toughness was also improved from 120 to $266 \mathrm{~J}$. Hardness values measured across the welds indicate that the use of the magnetic field during welding yields welds suitable for withstanding sulphide stress cracking.
\end{abstract}

Keywords: API X-65, MIG, Magnetic field, Welding, Acicular ferrite

\section{Introduction}

The pipe grades available for energy pipelines have been steadily increasing over the last few decades in virtue of the demand for oil and natural gas as a primary energy source. Many high-grade pipelines have been developed for offshore and onshore applications ${ }^{1-8}$, through adding microalloying elements, thermomechanically controlled process (TMCP) and other processes ${ }^{9,10}$, inducing a higher capacity for hydrocarbon transportation and significant cost savings by reducing the pipe wall thickness X65 grade steel is commonly used for manufacturing pipe for transporting hydrocarbons $\mathrm{s}^{11-16}$. Recently, the authors demonstrated that X65 grade steel may reach similar tensile strength to that presented by the $\mathrm{X} 80$ grade steel via a non-conventional heat treatment ${ }^{17}$. However, preliminary welding trials of this heat treated steel exhibited low mechanical resistance as a result of significant levels of porosity in the weld bead. An alternative to overcome this problem is the application of a magnetic field during welding.

It is known that the application of magnetic fields during the welding process improved the mechanical and corrosion properties of stainless steels ${ }^{18-24}$, aluminum alloys ${ }^{25,26}$ and other steels $^{27-29}$ and alloys ${ }^{30-32}$. While high magnetic fields have been employed to modify solid phase transformations ${ }^{24,29}$, magnetic fields in the order of a few $\mathrm{mT}$ are used during arc welding in order to modify the grain structure of the weld bead ${ }^{22,23,25,27}$. In principle, an external magnetic field

\footnotetext{
${ }^{1}$ Article presented and selected from "The XXIV International Materials Research Congress (IMRC) 2015". Symposium 5B "Structural and Chemical Characterization of Metals, Alloys and Compounds". Cancun, Mexico August 16-20, 2015.

* e-mail: consnatividad@yahoo.com.mx
}

applied to the weld pool induces electromagnetic stirring and changes the convective patterns within the weld pool. This perturbation modifies the solidification mode and may leads to a grain refinement effect in the weld bead ${ }^{22,23,25}$. The mechanisms by which these changes occur are dependant on the chemical nature of the alloy. The effect of applying magnetic fields for welding microalloyed steels has been little studied. García et al. ${ }^{27,28}$ studied an API X-65 microalloyed steel welded under the action of an axial magnetic field by fitting a MIG torch into electrogas process to weld plates of $12.5 \mathrm{~mm}$ in thickness. Microstructural characterization of the welds revealed an extensive grain refinement due to heterogeneous nucleation in the weld metal produced by an extended undercooling. Besides, the electromagnetic stirring also minimised and suppressed extensive epitaxial and columnar growth, respectively ${ }^{27,28}$.

The aim of this study is to assess the effect of applying an axial magnetic field during MIG welding of API X-65 steel plates hardened by a non-conventional heat treatment ${ }^{17}$ in order to improve the mechanical properties by modifying its microstructure and preventing defects.

\section{Experimental}

The material used in this study was API 5L X65 steel pipeline (outside diameter $609.6 \mathrm{~mm}$ and wall thickness 14.27 $\mathrm{mm}$ ) and a filler wire ER70S-6, $1.5 \mathrm{~mm}$ in diameter, was employed to deposit the weld beads. The chemical composition of both materials is given in Table 1. Specimens of $12 \mathrm{~mm}$ 
Table 1: Chemical composition of API X65 steel and filler metal (wt.\%).

\begin{tabular}{lccccccccccccc}
\hline & $\mathrm{C}$ & $\mathrm{Mn}$ & $\mathrm{Si}$ & $\mathrm{P}$ & $\mathrm{S}$ & $\mathrm{Al}$ & $\mathrm{Nb}$ & $\mathrm{Cu}$ & $\mathrm{Cr}$ & $\mathrm{Ni}$ & $\mathrm{V}$ & $\mathrm{Ti}$ \\
\hline X65 & 0.04 & 1.4 & 0.25 & 0.01 & 0.002 & 0.04 & 0.04 & 0.09 & 0.02 & 0.5 & 0.06 & 0.01 \\
ER70S-6 & 0.105 & 1.63 & 0.10 & 0.025 & 0.035 & - & - & 0.5 & 0.15 & 0.15 & 0.03 & - \\
\hline
\end{tabular}

x $70 \mathrm{~mm}$ x $150 \mathrm{~mm}$ were heat treated at $1050^{\circ} \mathrm{C}$ for $30 \mathrm{~min}$ and cooled in water ${ }^{17}$. This non-conventional heat treatment was performed to provide a microstructure composed of fine acicular ferrite and increased the mechanical strength of the steel. Subsequently, the specimens were machined to form a double $\mathrm{V}$ joint. Welding was carried out by using the MIG process with the mixture $98 \% \mathrm{Ar}+2 \% \mathrm{O}_{2}$ as shielding gas, flowing at $23.59 \mathrm{~L} / \mathrm{min}$. The filler wire was fed at 125 $\mathrm{mm} / \mathrm{s}$ whereas voltage $(25 \mathrm{~V})$ and current $(300 \mathrm{~A})$ were adjusted to maintain an approximate heat input of $1.74 \mathrm{~kJ} /$ $\mathrm{mm}$ considering an efficiency of $75 \%$ for the MIG welding process. The welding torch was displaced at $3.2 \mathrm{~mm} / \mathrm{s}$ with a stick out of $12 \mathrm{~mm}$. For the sake of comparison, the API 5L X65 plates were plainly welded and with the application of an axial external magnetic field of $6 \mathrm{mT}$. The experimental set up for the latter case is shown in Figure 1.

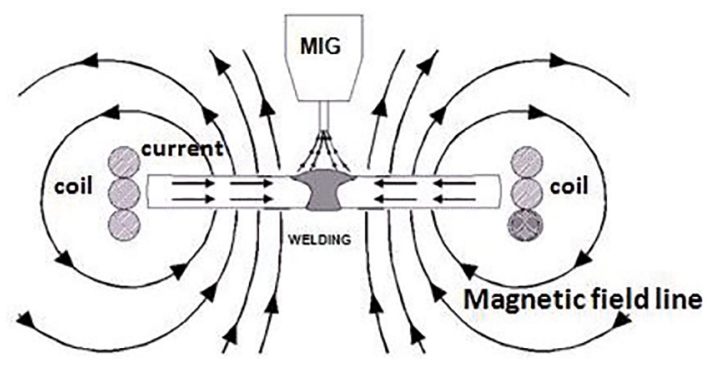

Figure 1: Experimental set-up for the application of axial magnetic field $^{20}$.

Microstructural characterization of the welds was performed in transverse cuts from the welds. Standard metallographic procedures were followed to obtain polished samples of the welds by grinding with silicon carbide papers and polishing with diamond suspensions. Specimens were etched with a solution of Nital diluted $2.5 \%$ to reveal the different regions of the welds and its microstructure. Analysis of the welds was performed in an optical microscope (OM) equipped with a digital camera.

The mechanical characterization of the welds comprised microhardness measurements, tensile and impact testing. Vickers microhardness profiles of the welds were obtained applying a load of $100 \mathrm{~g}$ during 15 seconds. The distance between measurements was of $250 \mathrm{~mm}$. Tensile tests were performed in dog bone shape specimens according to the ASTM E8/E8M standard ${ }^{33}$, with a cross head speed of $0.016 \mathrm{~mm} / \mathrm{s}$. Impact tests with Charpy V-notch specimens $(\mathrm{CVN})$ of dimensions $10 \times 10 \times 55 \mathrm{~mm}$ were carried out at $0^{\circ} \mathrm{C}$ according to ASTM E23 $3^{34}$. The fracture of the specimens was observed in the scanning electron microscope (SEM) equipped with an energy dispersive X-ray (EDX) detector.

\section{Results and discussion}

Figure 2a shows a transverse view of the plain weld. Chemical etching clearly revealed the weld beads, heat affected zones and non heat affected base material. To the naked eye, the weld seems to be sound; however, lack of lateral fusion was seen in the OM at the mid height of the weld. Figure $2 \mathrm{~b}$ exhibits the typical columnar grain growth following the heat source in the weld bead (WB). The interface between the WB and the heat affected zone (HAZ) is shown in Figure 2c. Besides the usual epitaxial and columnar grain growth, significant levels of porosity are observed in the WB. In fact, pores were seen throughout the WB. Observation of the reheated zone (RHZ), Figure $2 \mathrm{~d}$, revealed the presence of some levels of very fine porosity in the base metal.
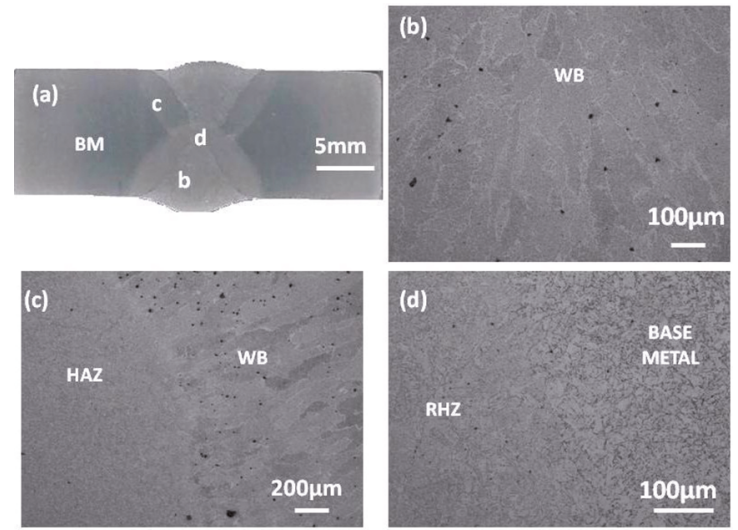

Figure 2: Microstructures obtained by optical microscopy of API X65 weldment without application of magnetic field.

Macro and microstructural characteristics of the welds obtained with the application of the axial magnetic are presented in Figure 3. Fully penetrated welds were produced without problems of lateral fusion. In comparison to the plain welds, the high levels of porosity in the weld bead were significantly reduced with the application of the axial magnetic field. This effect is explained in terms of the electromagnetic stirring of the weld pool and the direction of the magnetic flux lines that favor rejection of the gas within the weld pool toward the top ${ }^{19,27}$. Another distinctive microstructural feature is that the columnar grains are larger in length but shorter in width for the weld with magnetic field as compared to the plain weld. Electromagnetic stirring of the weld pool is expected to induce a grain refinement effect, this is not, however, the case. This phenomenon is also ascribed to the direction of the flux lines of the axial magnetic field. Columnar grain growth is caused by the thermal gradient within the weld pool and is enhanced in this instance due to the ferromagnetic nature of the base metal and filler wire. 


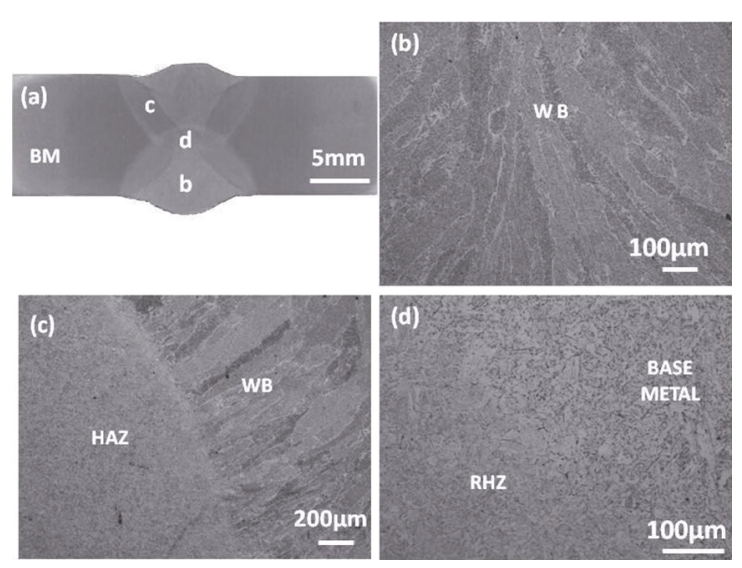

Figure 3: Microstructures obtained by optical microscopy of API X65 weldment with application of magnetic field

Generally speaking, the type of microstructure obtained in the welds optimizes the strength and the toughness of the weld beads ${ }^{8,14}$. Figure 4 a shows representative stress-elongation curves for welds obtained with and without application of magnetic field and Table 2 lists the result of tension and impact tests. The weld with the application of magnetic field exhibited a larger tensile strength as compared with the plain weld. Whereas welds with magnetic field failed under tensile stress in the base metal far from the WB, the specimens of the plain welds broke in the WB as shown in the macrographs $b$ and c, respectively, of Figure 4. This behavior was expected on basis of the microstructural findings. Figure $4 \mathrm{c}$ suggests that failure initiated at the lack of fusion defect observed at the mid height of the weld and probably propagated across the pores in the WB close to the fusion line. Suppression and minimization of defects when welding with the external axial magnetic field led to failure of the weld in the base metal with superior strength and ductility. The mechanical strength of the welds is, however, well below the values registered for the steel plates with the non-conventional heat treatment ${ }^{17}$ and more work needs to be done aiming to increase the mechanical efficiency of the welded joint. From the impact results, it is observed that toughness was enhanced twice by the application of magnetic field. This is also the result of the improvement in the soundness of the weld with the electromagnetic stirring.

In the fracture surfaces analyzed by SEM, it is evident the weld without magnetic field exhibited a mix ductile-brittle fracture, which is shown in Figure 5. Figure 5a shows a region of the fracture with a brittle and transgranular appearance. The micrographs of Figures $5 \mathrm{~b}$ and $\mathrm{c}$ present the typical features of a ductile fracture characterized by micro plastic deformation and extensive presence of microvoids nucleated at some metallic inclusions. At the bottom of large microvoids there are big globular or irregular inclusions. Figure 5d shows the EDX spectra corresponding to these inclusions, which could be $\mathrm{SiO}_{2}, \mathrm{TiC}$ and $\mathrm{Al}_{2} \mathrm{O}_{3}$ mainly. Figure 6 shows

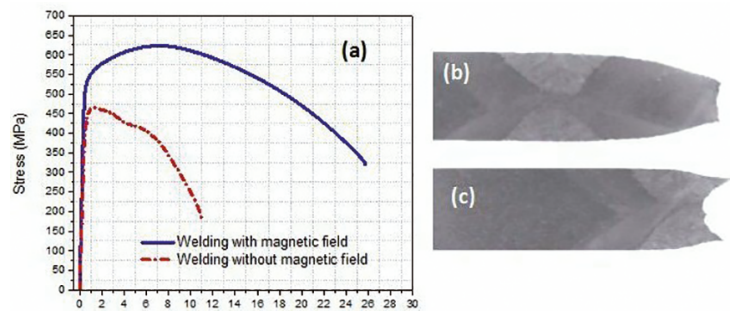

Figure 4: (a) Stress-elongation curves obtained from API X65 weldments and macrographs from fractured samples: (b) with magnetic field and (c) without magnetic field.

Table 2: Summary of mechanical properties obtained for API X65 steel weldments with and without magnetic field.

\begin{tabular}{lcccccc}
\hline $\begin{array}{l}\text { Steel } \\
(\mathrm{X}-65)\end{array}$ & $\begin{array}{c}\text { UTS } \\
(\mathrm{MPa})\end{array}$ & $\begin{array}{c}\text { YS } \\
(\mathrm{MPa})\end{array}$ & $\begin{array}{c}\sigma_{\text {RUPTURE }} \\
(\mathrm{MPa})\end{array}$ & $\begin{array}{c}\text { EL } \\
(\%)\end{array}$ & $\begin{array}{c}\text { EA } \\
(\mathrm{J})\end{array}$ & $\begin{array}{c}\text { Failure } \\
\text { Zone }\end{array}$ \\
\hline $\begin{array}{l}\text { With axial } \\
\text { magnetic } \\
\text { field }\end{array}$ & 625 & 537 & 324 & 26 & 266 & $\begin{array}{c}\text { Base } \\
\text { Metal }\end{array}$ \\
$\begin{array}{l}\text { Without } \\
\text { magnetic } \\
\text { field }\end{array}$ & 465 & 454 & 175 & 11 & 120 & $\begin{array}{c}\text { Fusion } \\
\text { Line }\end{array}$ \\
\hline
\end{tabular}

UTS: Ultimate tensile strength, YS: Yield strength, $\sigma_{\text {RUPTURE }}:$ Fracture stress or rupture strength, EL: Elongation, EA: Energy Absorbed.
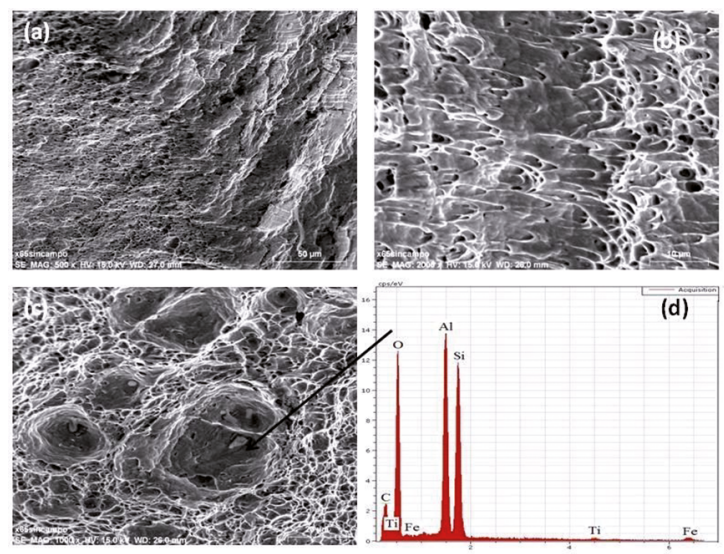

Figure 5: SEM micrographs of sample fractured after tensile tests without magnetic field; (a) brittle fracture zone, (b) ductile-brittle zone, (c) globular inclusions and (d) EDS from inclusions.

fracture micrographs obtained from the weld with magnetic field. The features of this fracture are similar to the plain weld but with signs of major plastic deformation. EDX data of the inclusions revealed that these were mainly composed by $\mathrm{Fe}, \mathrm{Mn}, \mathrm{Al}, \mathrm{S}, \mathrm{Mg}$ and $\mathrm{Ca}$. These compounds can form iron manganese $(\mathrm{MnS})$ globular inclusions or Fe-Mn-S as reported in the literature ${ }^{35,36}$.

Finally, Figure 7 shows microhardness profiles obtained from both welds at two positions; root pass and top bead. Obviously, the width of the second weld bead (top) is larger than the first (root) pass due to the greater dilution favored by preheating of the plates as a result of the heat input of the first pass. In general, the microhardness values obtained 


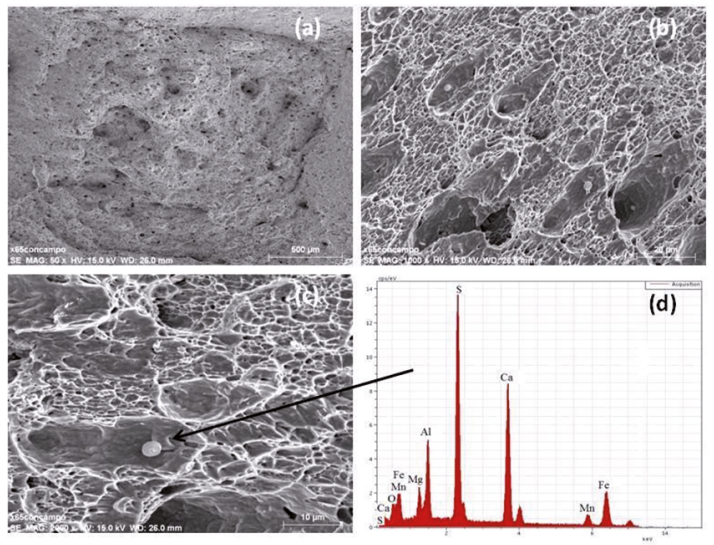

Figure 6: SEM micrographs of sample fractured after tensile tests with magnetic field, (a) ductile fracture, (b) ductile zone, (c) globular inclusions and (d) EDS from inclusions
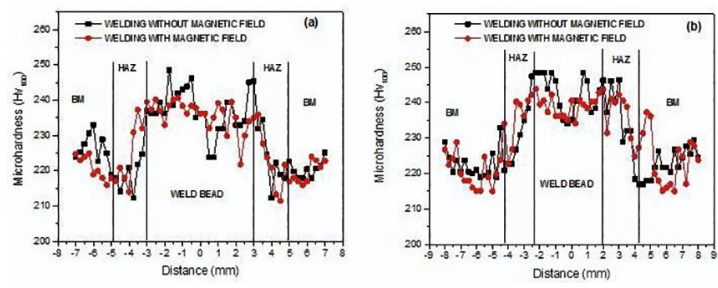

Figure 7: Microhardness profiles measurements in (a) top bead and (b) root pass.

for the welds with the application of magnetic field were smaller than those obtained without magnetic field. These values remain below the acceptable hardness limits for welds to withstand sulphide stress cracking (SSC) ${ }^{37,38}$. Hardness control may be an acceptable parameter in order to determine suitability for SSC resistance ${ }^{37}$.

\section{Conclusions}

Applying an external axial magnetic field during welding, the defects (porosity and lack of lateral fusion) produced by welding without application of magnetic field was eliminated. Therefore, the mechanical properties of the welds were improved. Welded samples without magnetic field subjected to tensile test failed in WB. With the application of magnetic field during welding, the toughness was improved more than twice, from 120 to $266 \mathrm{~J}$. This was due to grain refinement of the microstructure in the weld bead and significant reduction in porosity. Hardness values obtained for welds with magnetic field are lower than values measured for plain welds. These values remain below the acceptable hardness limits for welds to withstand SSC.

\section{Acknowledgments}

The authors would like to thanks CONACYT and CIC of the UMSNH for financial support.

\section{References}

1. Ishikawa N. Material development in recent high-grade linepipes. Journal of the Japan welding society. 2007; 76(7):525-529. http://doi.org/10.2207/jjws.76.525

2. Soeiro Junior JC, Rocha DB, Brandi SD. A brief history review of development on API steels welding for pipeline. Soldagem e Inspeção. 2013;18(2):176-195.

3. Yoo JY, Ahn SS, Seo DH, Song WH, Kang KB. New development of high grade X80 to X120 pipeline steels. Materials and Manufacturing Processes. 2011;26(1):154-160.

4. Felber S. Mechanical-technological and fracture mechanical properties of the high grade pipeline-steel X80 with results of different pipeline-projects. Welding in the World. 2008;52(5):42-50.

5. Ferino J, Fonzo A, Di Biagio M, Demofonti G, Spinelli CM, Karamanos SA. Onshore pipeline high-grade steel for challenge utilization. In: Proceedings of the $24^{\text {th }}$ International Offshore and Polar Engineering Conference; 2014 June 15-20; Busan, Korea. Code 107291. p. 39-46.

6. Lei X, Wu K, Wang H, Yu L. Microstructure evolution and alloying features of a developed high strength and high toughness weld metal used for pipeline steels. Journal of Coastal Research. 2014;73(Sp Is):265-269.

7. Wiebe J, Bruns C, Toma D. Weldabilty of Heavy Wall Seamless Line Pipe Steel X80. In: Proceedings of the $23^{\text {rd }}$ International Offshore and Polar Engineering Conference; 2013 June 30-July 5; Ancorage, Alaska, USA. p. 171-177.

8. Zhang M, Yang L, Li JH. Submerged Arc Welding X 100 Pipeline Steels. Materials and Manufacturing Processes. 2014;29(1):64-68.

9. Bauer J, Flüss P, Amoris E, Schwinn V. Microstructure and properties of thermomechanical controlled processing steels for linepipe applications. Ironmaking and Steelmaking. 2005;32(4):325-330.

10. Lakshminarasimham B, Wadnerkar R, Borkar M. Steel plate processing for line pipes in oil and gas transport - A manufacturer perspective. In: Materials Science and Technology Conference and Exhibition 2012; 2012 Oct 7-11; Pittsburgh, PA, USA. p. 917-928.

11. Hashemi SH. Strength-hardness statistical correlation in API X65 steel. Materials Science and Engineering: A. 2011;528(3):16481655.

12. Simpson ID, Tritsiniotis Z, Moore LG. Steel cleanness requirements for X65 to X80 electric resistance welded linepipe steels. Ironmaking \& Steelmaking. 2003;30(2):158-164.

13. Alawadhi K, Robinson MJ. Preferential weld corrosion of X65 pipeline steel in flowing brines containing carbon dioxide. Corrosion Engineering, Science and Technology. 2011;46(4):318-329.

14. Hashemi SH, Mohammadyani D. Mechanical Characteristics of Submerged Arc Weldment in API Gas Pipeline Steel of Grade X65. AIP Conference Proceedings. 2011;1315(1):872-877.

15. Hashemi SH, Mohammadyani D. Characterization of weldment hardness, impact energy and microstructure in API X65 steel. International Journal of Pressure Vessels and Piping. 2012;98:8-15.

16. Ju JB, Kim WS, Jang JI. Variation in DBTT and CTOD within weld heat-affected zone of API X65 pipeline steel. Materials Science and Engineering: A. 2012;546:258-262. 
17. Natividad Murillo C, García Hernández R, López Morelos VH, Salazar Martínez M. Improvement of mechanical properties of API X-65 steel by non-conventional heat treatment. In: Pérez Campos R, Contreras Cuevas A, Esparza Muñoz R, eds. Materials Characterization, Part III. Cham: Springer International Publishing; 2015. p. 71-77.

18. García-Rentería MA, López-Morelos VH, García-Hernández R, Dzib-Pérez L, García-Ocha EM, González-Sánchez J. Improvement of localized corrosion resistance of AISI 2205 Duplex Stainless Steel joints made by gas metal arc welding under electromagnetic interaction of low intensity. Applied Surface Science. 2014;321:252-260.

19. García Rentería MA, López Morelos VH, García Hernández R, Curiel LópezF, Lemus-Ruíz J. Effect on the microstructure and mechanical properties of the electromagnetic stirring during GMA welding of 2205 DSS plates. Materials Science Forum. 2013;755:61-68.

20. Curiel FF, García R, López VH, González-Sánchez J. Effect of magnetic field applied during gas metal arc welding on the resistance to localised corrosion of the heat affected zone in AISI 304 stainless steel. Corrosion Science. 2011;53(7):2393-2399.

21. Curiel FF, García R, López VH, García MA, Lemus J. Transmission Electron Microscopy in the Heat Affected Zone of an AISI 304 Austenitic Stainless Steel Welded with the Application of a Magnetic Field of Low Intensity. Materials Transactions. 2013;54(1):122-125.

22. Malinowski-Brodnicka M, den Ouden G, Vink WJP. Effect of electromagnetic stirring on GTA welds in austenitic stainless steel. Welding Research Supplement. 1990;69(2):52S-59S.

23. Villafuerte JC, Kerr HW. Electromagnetic stirring and grainrefinement in stainless-steel GTA welds. Welding Research Supplement. 1990;69(1):S1-S13.

24. San Martín D, Aarts KWP, Rivera-Díaz-del-Castillo PEJ, van Dijk NH, Brück E, van der Zwaag S. Isothermal martensitic transformation in a $12 \mathrm{Cr}-9 \mathrm{Ni}-4 \mathrm{Mo}-2 \mathrm{Cu}$ stainless steel in applied magnetic fields. Journal of Magnetism and Magnetic Materials. 2008;320(10):1722-1728.

25. Matsuda F, Nakagawa H, Nakata K, Ayani R. Effect of electromagnetic stirring on weld solidification structure of aluminum alloys (Report I): Investigation on GTA weld metal of thin sheet. Transactions of Joining and Welding Research Institute (JWRI). 1978;7(1):111-127.

26. García Rentería MA, López Morelos VH, García Hernández R, Curiel López F, Ambriz-Rojas RR. Preliminary assessment of the effects of the application of an axial magnetic field during GMA welding of Al-6063-T6. MRS Proceedings. 2010;1275:S3-21.

27. Garcia R, López VH, Lazaro Y, Aguilera J. Grain refinement in electrogas welding of microalloyed steels by inducing a centered magnetic field. Soldagem e Inspeção. 2007;12(4):300-304.
28. García R, López VH, Lázaro Y. Efecto de la polaridad eléctrica en la soldadura de un acero API X-65 mediante la adaptación del proceso de soldadura MIG a soldadura por electrogas con agitación magnética. Revista Latinoamericana de Metalurgia y Materiales. 2009;S1(2):697-703.

29. Nakamichi S, Tsurekawa S, Morizono Y, Watanabe T, Nishida M, Chiba A. Diffusion of carbon and titanium in $\gamma$-iron in a magnetic field and a magnetic field gradient. Journal of Materials Science. 2005;40(12):3191-3198.

30. Campanella T, Charbon C, Rappaz M. Grain refinement induced by electromagnetic stirring: A dendrite fragmentation criterion. Metallurgical and Materials Transactions A . 2004;35(10):32013210.

31. Sivaprasad K, Raman SG. Influence of magnetic arc oscillation and current pulsing on fatigue behavior of alloy 718 TIG weldments. Materials Science \& Engineering: A. 2007;448 (1-2):120-127.

32. McCracken SL, Yu X, Lim YC, Farson DF, Babu SS. Grain structure refinement in nickel alloy welds by magnetic arc stirring. In: ASME 2011 Pressure Vessels and Piping Conference; 2011 Jul 17-21; Baltimore, Maryland, USA. Paper No. PVP201157681, p. $1565-1577$.

33. ASTM International. ASTM E8/E8M Standard test methods for tension testing of metallic materials. West Conshohocken: ASTM International; 2013.

34. ASTM International. ASTM E23 Standard test methods for tension testing of metallic materials. West Conshohocken: ASTM International; 2012.

35. Ray A, Paul SK, Jha S. Effect of inclusions and microstructural characteristics on the mechanical properties and fracture behavior of high- strength low- alloy steel. Journal of Materials Engeneering and Performance. 1995;4(6):679-688.

36. Zachrisson J, Börjesson J, Karlsson L. Role of inclusions in formation of high strength steel weld metal microstructures. Science and Technology of Welding and Joining. 2013;18(7):603-609.

37. NACE International. NACE MR0175-2002, MR0175/ISO 15156 Petroleum and natural gas industries - Materials for use in $\mathrm{H}_{2} \mathrm{~S}$-containing environments in oil and gas production Part 1: General principles for selection of cracking-resistant materials. Houston: NACE International; 2009.

38. European Federation of Corrosion. EFC 16 Guidelines on materials requirements for carbon and low alloy steels for $\mathrm{H}_{2} \mathrm{~S}$-containing environments in oil and gas production. Leeds: European Federation of Corrosion Publications; 2009. 